\title{
Critical Factors for Selecting a Neutral to Support Alternative Dispute Resolution Methods in the Construction Industry
}

\author{
A. Saeb ${ }^{a^{*}}$, O. Mohamed ${ }^{a}$, M. S. Mohd Danuri ${ }^{b}$, N. Zakaria ${ }^{c}$ \\ ${ }^{a}$ Dept. of Quantity Surveying, Faculty of Built Environment, University of Malaya, Malaysia.
}

Received 05 December 2017; Accepted 24 January 2018

\begin{abstract}
Alternative dispute resolution methods (ADR) were developed in the construction industry to acquire suitable solutions. These methods are classified based on the role of the third party (neutral). Third-parties can play multiple roles in the ADR process including a facilitative, advisory, determinative or combined. The authorities of the third-party in the types of ADR techniques are different. Despite the importance of a third party in the ADR process, previous studies are not clearly identified factors for selecting them. The purpose of this research is to provide critical factors for neutral to support ADR methods in the construction industry. This research also, highlights the role of neutral in common ADR techniques. Random sampling was used for quantitative data collection. Of the 200 experts invited to fill in the questionnaire, 112 experts participated. To provide critical factors the factor analysis was used. The research found four critical factors for selecting supporting ADR neutrals in construction including; familiarity with legal and technical issues, being accepted by parties, efficiency and fairness. It can be concluded that selecting neutral party using the critical factors is efficient because the selection of a third-party in ADR is based on many variables is very difficult.
\end{abstract}

Keywords: Construction Claims; Disputes resolution; Neutral; ADR.

\section{Introduction}

Construction projects are now reaching megaproject size, therefore the structure of construction parties is becoming increasingly complicated and the level of disputes more serious [1,2]. The success of a construction project depends on the coordinated efforts of the project team members. This is especially crucial when a project is in dispute and therefore the achievement of a satisfactory resolution in the projects is fundamental to the success of the project [3]. Some studies have identified that the inadequate resolution of a dispute will jeopardize the project's success [4]. In the last two decades, the construction industry has been notorious for investigating the nature and growing number of disputes [5] and is known for its continuous efforts in developing more efficient methods for dispute resolution [6]. The large amounts of time and money spent by all parties involved in litigation [7] have led to the innovation of other dispute resolution methods [8 and 9], called Alternative Dispute Resolution (ADR) techniques [10]. The main purpose of ADR techniques is to resolve disputes with the least possible intervention by an outside neutral [11]. In recent years ADR has emerged as a popular means to resolve both public and private disputes [12, 13]. However, the use of ADR is still at its embryonic stage in the many countries [14].

Figure 1. illustrates a continuum of dispute resolution procedures with control over the outcome which is compared with an assumed escalating degree of resolution costs and hostilities. An increase in Neutral authority control of the outcome reduces and increase hostilities.

\footnotetext{
* Corresponding author: saeb.abdollah@siswa.um.edu.my

doi) http://dx.doi.org/10.28991/cej-030965

$>$ This is an open access article under the CC-BY license (https://creativecommons.org/licenses/by/4.0/).

(C) Authors retain all copyrights.
} 
Neutrals can play facilitative, advisory, determinative or combined, roles in ADR methods. The authority of the neutrals in ADR methods is different. Despite the importance of the neutral in ADR, studies on the matter of using a defined criterion for the selection process are insufficient. This research provides critical factors for neutral in ADR in construction. This research also, highlights neutrals roles in common ADR techniques in the construction industry.

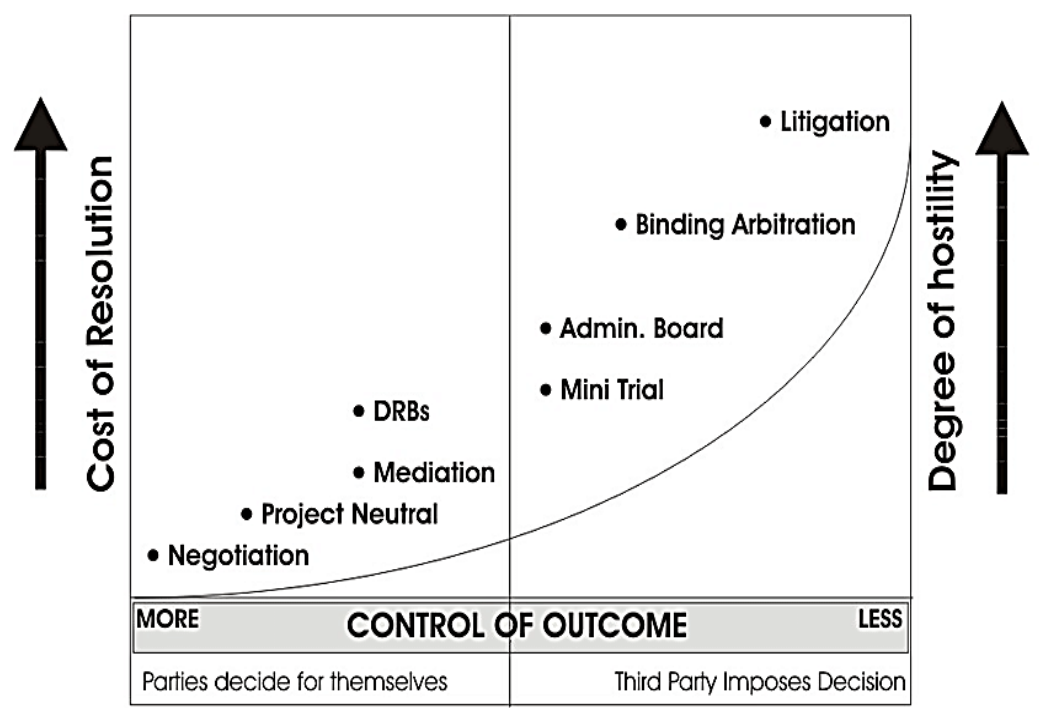

Figure 1. Dispute resolution continuum [15]

\section{Alternative Dispute Resolution}

Despite the Civil arbitration goes back to ancient times [16, 17], the "Alternative Dispute Resolution" term is fairly new and it was not until the 1970s that ADR emerged as a field of study in law [18]. ADR covers all legally permissible processes of dispute resolution other than litigation [19-21]. Now ADR methods are used widely in order to resolve disputes more efficiently, confidentially and at a lower cost than litigation. They can also help parties find practical, commercial solutions to disputes, allowing them to maintain on-going business relationships [22]. Figure 2. shows common Alternative Dispute Resolution methods in the construction industry.

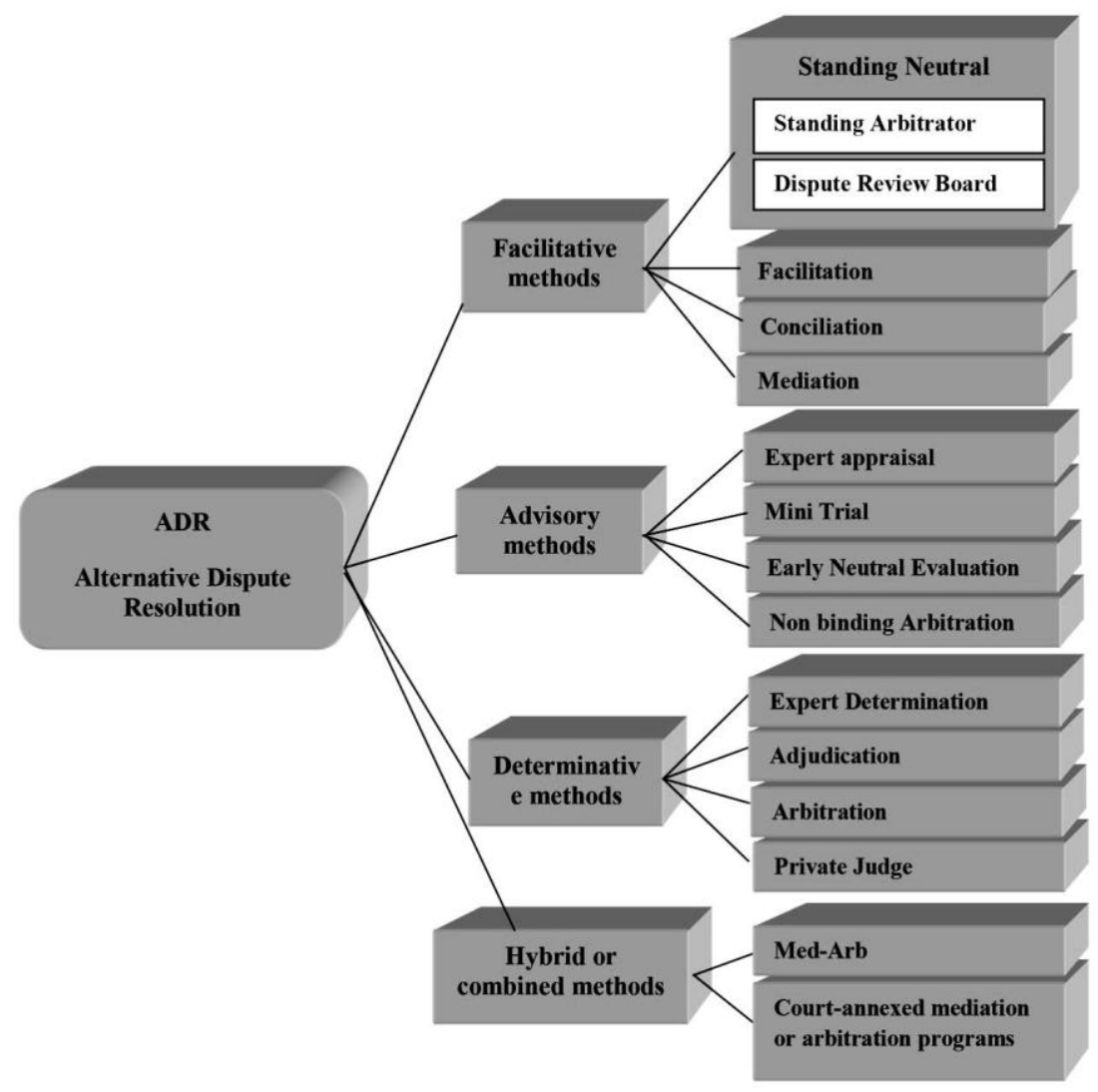

Figure 2. Alternative Dispute Resolution methods in construction industry 


\subsection{Neutral's Roles in Alternative Dispute Resolution Methods}

The National Alternative Dispute Resolution Advisory Council (NADRAC) classified ADR methods by the role and authority of the neutral. The neutral plays facilitative, advisory, determinative or combined, roles in ADR methods [23]. Neutral roles in the various types of ADR techniques were summarized in Table 1.

Table 1. Neutral's roles in ADR techniques

\begin{tabular}{|c|c|c|}
\hline ADR methods & ADR techniques & Neutral's role in ADR techniques \\
\hline \multirow[t]{4}{*}{ Facilitative } & Standing Neutral & Investigating win-win solutions to develop an agreeable resolution [24- 26]. \\
\hline & Facilitation & $\begin{array}{l}\text { Identify problems to be solved, tasks to be accomplished or disputed issues to be } \\
\text { resolved. Assist the parties to develop options [23]. }\end{array}$ \\
\hline & Conciliation & $\begin{array}{l}\text { Develop options, consider alternatives and endeavour to reach an agreement. A } \\
\text { conciliator may have an advisory role on the content of the dispute or the outcome of } \\
\text { its resolution. [23]. }\end{array}$ \\
\hline & Mediation & $\begin{array}{l}\text { To guide the parties toward the resolution of the dispute. Works together with the } \\
\text { parties as a partner to assist them in finding the best solution to further their interests } \\
{[27-29] \text {. }}\end{array}$ \\
\hline \multirow[t]{4}{*}{ Advisory } & Expert appraisal & $\begin{array}{l}\text { Investigates the dispute and provides advice on the facts with possible, desirable } \\
\text { outcomes and the means whereby these may be achieved [ } 23 \text { and } 30] \text {. }\end{array}$ \\
\hline & Mini Trial & $\begin{array}{l}\text { Assess the situation, and make non-binding conclusions regarding the outcomes and } \\
\text { the means whereby these may be achieved [31-33]. }\end{array}$ \\
\hline & Early Neutral Evaluation & Evaluate the dispute and issue a non-binding assessment. [34-36 ]. \\
\hline & Nonbinding Arbitration & Issue an advisory award or a prediction of the likely award [37and 38]. \\
\hline \multirow[t]{4}{*}{ Determinative } & Expert Determination & Investigate the dispute and make a decision [23and39]. \\
\hline & Adjudication & Investigate the dispute and make a decision [40-42]. \\
\hline & Arbitration & Investigate the dispute and make a final decision [43-45]. \\
\hline & Private Judge & $\begin{array}{l}\text { Investigate the dispute and make a determination by their opinion as to what decision } \\
\text { would be made if the matter was judicially determined [23and 46]. }\end{array}$ \\
\hline \multirow{3}{*}{$\begin{array}{l}\text { Combined or } \\
\text { Hybrid methods }\end{array}$} & Med-Arb & Play a mediator's role then play an arbitrator's role [36, 47 and 48$].$ \\
\hline & Court-annexed mediation & Like mediator's role [49 and 50]. \\
\hline & Court-annexed arbitration & Like arbitrator's role [49 and 50]. \\
\hline
\end{tabular}

\subsection{Neutral's Critical Characteristics for ADR Methods in Construction Industry}

Neutral's intervention has found strong expression in the field of dispute resolution, and yet there remains significant potential for improvement in both theory and practice. (51) The literature above shows of the role neutral in ADR methods. The Iranian Parliament Strategic Research Center emphasized the importance of selecting a neutral for ADR [52], however, there are few studies on this issue. ASCE [26] described the third-party for Standing Neutral as an experienced and trusted construction professional with appropriate technical background. According to Pena-Mora et al., the standing arbitrator is chosen by the project participants based on his/her experience with the particular type of construction (37). NADRAC described the third-party for Expert Determination technique as an experienced in the subject matter of the dispute [23]. Evans [53] conducted comprehensive research on the characteristics of a neutral for ADR in construction. But he had used descriptive statistics and reflected the frequency of a large number of effective variables in selection neutral for resolving construction disputes His findings are as follows.

a. The personal characteristics of third-parties in ADR for construction in order of importance are as follows: Honest, No conflict of interest, Has integrity, Non-biased, Fair, Impartial, Uses good judgment, Open minded, Good listener, Good communicator, Patient, Has cool or low-keyed temperament, judicious temperament, Mature and Humble.

b. They must have experience with the type of dispute.

c. Their technical competence is more important than professional reputation.

d. Their experiences of the neutral are more important than their knowledge.

e. Their technical qualifications are more important than personal characteristics.

\section{Research Methodology}

Quantitative data were collected via survey. Surveys provide a numeric description of the trends within or opinions of a population by systematically studying a sample of that population and then generalizing the results on the whole population. Survey researches go through questionnaires for data collecting [54]. Random sampling approach was 
followed for quantitative data collection. Probability sampling is the most popular approach in survey-based research strategies [55]. The questionnaire was extracted from a study by Evans [53]. The questionnaire was reviewed by 12 experts for pilot testing and gauges their level of understanding of the questions. A copy of the translated questionnaire can be found in the Appendix I. In this study to analyze quantitative data, descriptive statistical techniques and factor analysis were used by applying SPSS software version 20 .

\subsection{Research Population and Sample}

Iranian Construction Official Experts of grade E1 were defined as the most specialized group of experts. They had backgrounds as owners, contractors and consultants. Those official experts in the construction industry who are qualified to express their opinions regarding disputes between contractors, consultants and owners represent the best group upon which to undertake a quantitative survey, for the following reasons.

a. They are always involved in construction disputes.

b. They are professional group in this scope.

c. They have university degrees in construction-related majors, with their knowledge further evaluated via the entrance exam and interview.

d. They are familiar with legal system.

e. They have oath and are supposed to be neutral.

f. They have experience as contractors, consultants or owners as such experiences are mandatory to get qualified.

Those official experts in the construction industry who are certified to express their opinion regarding disputes between contractors, consultants and owners may have either of three grades namely E1 (highest) to E3 (lowest). They were selected as a sample in the population for this research. Of the 200 experts invited to fill in the questionnaire, 112 experts participated in the research. All participants had more than 10 years of experience as an official expert. Figure 3. also shows their years of experience as owners, contractors or consultants. $59.82 \%$ had more than 15 years and $91.96 \%$ had more than 10 years of working experience.

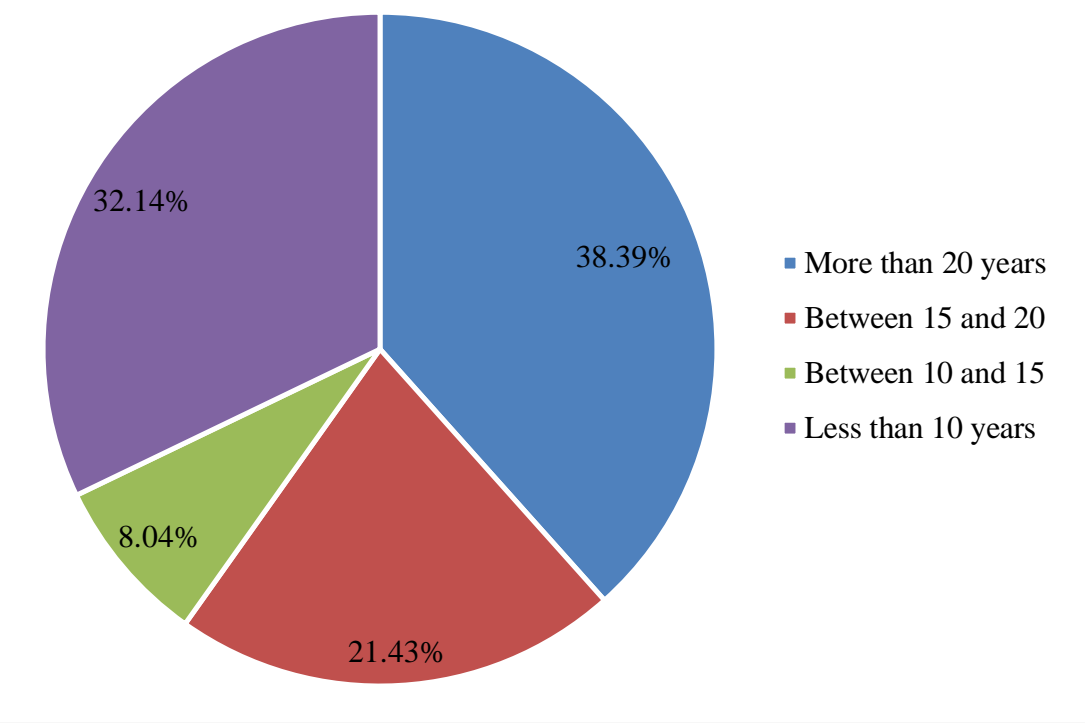

Figure 3. Experience of respondents

\subsection{Proportionality Test of Data for Factor Analysis}

The Kaiser-Meyer-Olkin measure was calculated to determine to what extent variables should be grouped and are appropriate for a factor analysis (56). In the current study, the Kaiser-Meyer-Olkin measure was 0.795 (Table 3) that greater than 0.70 was recommended for factor analysis (57).

Bartlett's test of sphericity determines whether or not the correlation matrix is an identity matrix that would deem a factor analysis inappropriate. Bartlett's Test of Sphericity found the approximate chi-square to be 1889.582 ( $d f=276$, significance 0.000 ), testifying to the appropriateness of the analysis and the reliability of the solution. Bartlett's test of the null hypothesis states that the variables in the correlation matrix are not related. As the value of the test increases [in this study, 1889.582] and associated significance decreases [in this study 0.000], the results indicate that the null hypothesis can be rejected (Table 2).

Table 2. KMO and Bartlett's Test 


\begin{tabular}{|c|c|c|}
\hline \multicolumn{3}{|l|}{ KMO and Bartlett's Test } \\
\hline \multicolumn{2}{|c|}{ Kaiser-Meyer-Olkin Measure of Sampling Adequacy } & 0.795 \\
\hline \multirow{3}{*}{ Bartlett's Test of Sphericity } & Approx. Chi-Square & 1889.582 \\
\hline & $d f$ & 276 \\
\hline & Sig. & 0.000 \\
\hline
\end{tabular}

\section{Results and discussion}

In following collected data from the respondents were analyzed and discussed.

\subsection{Importance of the Third-Party in Dispute Resolution}

The third-party's presence in dispute resolution processes is essential for achieve rapid solution. The importance of neutrals in helping dispute resolution corresponding to construction industry based on the interval measurement from 1 to 5 was investigated in the questionnaire. Figure 4. shows the obtained results after converting interval measurement to ordinal measurement. $77.68 \%$ assessed presence of the third party as important.

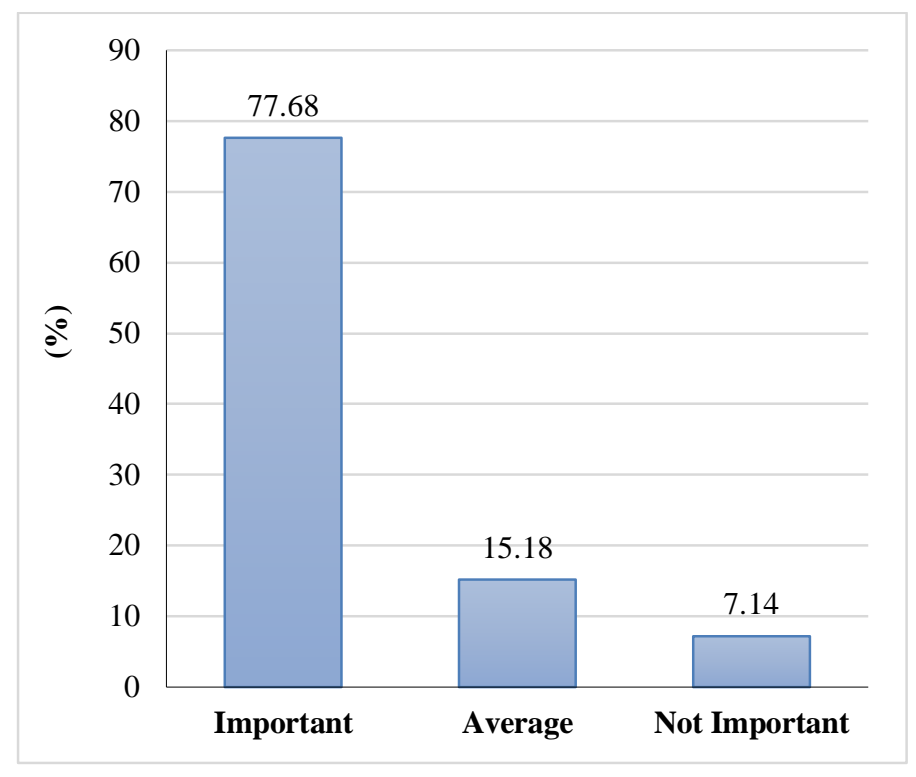

Figure 4. The importance of a third-party to resolving disputes

\subsection{Factors for Selecting Third-parties in ADR in the Construction Industry}

The selection of a third-party in ADR is based on many variables is very difficult, therefore, in this research the important factors are extracted using factor analysis to provide critical factors for neutral to supporting ADR methods in the construction industry. It used to identify the determinants third party factors from the 24 variables including; Experience in construction, Experience in construction disputes, Employed by project consultant, Employed by one of parties, Experience in similar project, Knowledge in similar construction, Experience in interpreting contract documents, Experience in contracting, Experience in similar dispute, Knowledge of construction disputes resolution, Non-biases, Patient, Good listener, Good communication skill, No emotional, Honest, Humble, Open-minded, Reliable, Judicious temperament, Uses good judgment, Fair, Don't give opinion without evidence, and No interest of conflict.

The factor analysis simplifies complex sets of data and is used to identify underlying constructs (factors) that explain correlations among a set of data. Essentially, they summarize a large number of items with a smaller number of derived items. The resultant factor loadings represent the correlation between each of the items (answers to a question) with each of the derived factors.

\subsubsection{Extraction of Factors}

A factor analysis was performed using a principal component extraction with a Varimax rotation. List wise deletion was used to handle missing values in the factor analysis. Factors selected for rotation had eigenvalues greater than 1. Items with factor loadings equal to or greater than .30 were acceptable, greater than .40 were considered significant, and loadings of .50 or greater were considered very significant [58 and 59]. Scales were interpreted by identifying those items with their highest factor loading on the same factor. Eighty-seven percent of the loaded items were very considered significant and others were considered significant and acceptable. 
Initially, an exploratory factor analysis was used. Only factors with an eigenvalue greater than 1 were considered for further analysis, which resulted in 6 factors. On the basis of eigenvalues and implications from the scree-test, 4 of the 6 factors were chosen. As can be seen in Table 3 the 4 factors represent $58 \%$ of the total variance in responses after varimax rotation. A scree plot indicated that 4 factors constituted an appropriate solution [60]. The first, second, and third factors accounted for $28 \%, 13 \%$, and $10 \%$ of the variance, respectively. Table 3 . details the 4 factors and the percent of variance each explains.

Table 3. The extracted factors

\begin{tabular}{cccc}
\hline Factor & Total & \% of variance & Cumulative \% \\
\hline 1 & 6.748 & 28.116 & 28.116 \\
2 & 3.169 & 13.205 & 41.321 \\
3 & 2.456 & 10.233 & 51.554 \\
4 & 1.596 & 6.649 & 58.204 \\
\hline
\end{tabular}

A principal component factor analysis with a varimax rotation was run. A varimax rotation was selected for the analysis because it is the most commonly used rotation and because it is relatively easy to interpret and use. Table 4 . shows a summary of items and factors.

Table 4. Summary of items and factors

\begin{tabular}{|c|c|c|c|c|c|}
\hline $\mathbf{Q}$ & Variable & F1 & F2 & $\mathbf{F 3}$ & $\mathbf{F 4}$ \\
\hline 1 & Experience in construction & 0.434 & & & 0.136 \\
\hline 2 & Experience in construction disputes. & 0.916 & 0.175 & & \\
\hline 3 & Employed by project consultant. & & -0.450 & 0.166 & -0.510 \\
\hline 4 & Employed by one of parties. & -0.374 & -0.576 & & -0.112 \\
\hline 5 & Experience in similar project & 0.944 & 0.153 & & 0.109 \\
\hline 6 & Knowledge in similar construction & 0.407 & & & 0.120 \\
\hline 7 & Experience in interpreting contract documents & 0.724 & & 0.101 & \\
\hline 8 & Experience in contracting & 0.868 & 0.161 & & 0.148 \\
\hline 9 & Experience in similar dispute & 0.945 & 0.131 & & \\
\hline 10 & Knowledge of construction disputes resolution & 0.278 & 0.325 & 0.414 & 0.186 \\
\hline 11 & Non-biases & 0.156 & & & 0.907 \\
\hline 12 & Patient & 0.258 & 0.302 & 0.378 & \\
\hline 13 & Good listener & & 0.797 & 0.172 & \\
\hline 14 & Good communication skill & 0.403 & 0.495 & & \\
\hline 15 & No emotional & & & 0.740 & -0.146 \\
\hline 16 & Honest & 0.344 & 0.595 & 0.300 & \\
\hline 17 & Humble & 0.365 & & 0.782 & \\
\hline 18 & Open-minded & -0.120 & & 0.730 & \\
\hline 19 & Reliable & 0.286 & 0.496 & 0.435 & \\
\hline 20 & Judicious temperament & 0.117 & & & -0.196 \\
\hline 21 & Uses good judgment & 0.104 & 0.139 & 0.349 & 0.118 \\
\hline 22 & Fair & & -0.135 & & 0.888 \\
\hline 23 & Don't give opinion without evidence & & 0.782 & & \\
\hline 24 & No interest of conflict. & & 0.736 & & \\
\hline
\end{tabular}

\subsubsection{Naming and meanings of the factors}

Naming should be done with respect to common meaning of the variables in which the factors have significant weight. I.e. this name should provide an appropriate meaning and concept for those variables. Albeit, it is natural that variables with higher factor loading are more important in naming [61]. Naming and meanings of the 4 factors were interpreted as follows:

Factor 1, familiarity with legal and technical issues: This factor shows that the third party selected for dispute resolution in the construction industry should have enough familiarity with both the legal and technical aspects of construction industry to identify the roots of the dispute and have an accurate deduction concerning technical and legal contract documents. This factor consisted of 7 items (positively worded) with loads greater than .407. Higher scores 
indicate stronger beliefs in the experience in similar project and experience in similar disputes. All Factor 1 items were very significant or significant.

Factor 2, being accepted by both parties: He/she should be independent and his/her opinions should be documented and can respond with reason to parties. This factor consisted of 7 items ( 6 positively worded and 1 negatively worded) with loads greater than .495 . The negatively worded items were reverse scored. Higher scores indicate stronger beliefs in the good listener and don't give opinion without evidence. All Factor 2 items were very significant or significant.

Factor 3, efficiency: The third-party must have essential knowledge and character for making peace and settlements. He/she must be familiar with dispute resolution techniques and for achieving settlements. They must also be patient and not overly sensitive. This factor consisted of 6 items (positively worded) with loads greater than .349. Higher scores indicate stronger beliefs in humble and no emotional. With the exception of two items, all Factor 3 items were very significant or significant.

Factor 4, fairness: They must be completely neutral, fair and not raise skepticism. This factor consisted of 3 items ( 2 positively worded and 1 negatively worded) with loads greater than .510 . The negatively worded items were reverse scored. Higher scores indicate stronger beliefs Neutral and Fair. All Factor 4 items were very significant.

Evans [53] had used descriptive statistics and reflected the frequency of effective variables in selection neutral for resolving construction disputes. In the Evans research; 'Honest, No conflict of interest, Fair, Integrity, Non biased and Uses good judgments' are the most frequency. Evans also found experience of neutrals was more important than their knowledge and technical qualifications were more important than personal characteristics for neutrals supporting ADR. The obtained factors in this research cover all introduced variables by Evens and converge with his findings.

\section{Conclusion}

The time and money spent by all parties involved in a dispute have led to the rise of alternative methods of dispute resolution, called Alternative Dispute Resolution (ADR) methods. The use of third-party in the ADR methods is important. These methods are classified based on the role of the third party. Third-parties can play multiple roles in the ADR process including a facilitative, advisory, determinative or combined. The authorities of the third-party in the types of ADR techniques are different. It can be concluded that selecting the third-party based on tested factors is important for the success of ADR techniques. The research identified four critical factors for selecting ADR thirdparties in construction which are as follows.

Factor 1, familiarity with legal and technical issues: This factor shows that the third party selected for dispute resolution in the construction industry should have enough familiarity with both the legal and technical aspects of construction industry to identify the roots of the dispute and have an accurate deduction concerning technical and legal contract documents.

Factor 2, being accepted by both parties: He/she should be independent and his/her opinions should be documented and can respond with reason to parties.

Factor 3, efficiency: The third-party must have essential knowledge and character for making peace and settlements. He/she must be familiar with dispute resolution techniques for achieving settlements. They must also be patient and not overly sensitive.

Factor 4, fairness; they must be completely neutral, fair and not raise skepticism.

\section{References}

[1] Lee, Changjun, Jin Woo Won, Woosik Jang, Wooyong Jung, Seung Heon Han, and Young Hoon Kwak. "Social Conflict Management Framework for Project Viability: Case Studies from Korean Megaprojects." International Journal of Project Management 35, no. 8 (November 2017): 1683-1696. doi:10.1016/j.ijproman.2017.07.011.

[2] Park, Chan, Seung Han, Kang-Wook Lee, and Yong Lee. "Analyzing Drivers of Conflict in Energy Infrastructure Projects: Empirical Case Study of Natural Gas Pipeline Sectors.” Sustainability 9, no. 11 (November 6, 2017): 2031. doi:10.3390/su9112031.

[3] Cheung, Sai On, Tak Wing Yiu, and Ho Wai Chan. "Exploring the potential for predicting project dispute resolution satisfaction using logistic regression." Journal of Construction Engineering and Management 136, no. 5 (2009): 508-517. DOI: 10.1061/(ASCE)CO.1943-7862.0000157.

[4] Werderitsch, Anthony J., and James E. Krebs. "Claims avoidance-a project management primer." AACE International Transactions (2000): R1A.

[5] Richbell, D. "Mediation of Construction Disputes, Blackwell Publishing Ltd". (2008). ISBN: 9781405169318.

[6] Hinchey, John W., and Laurence Schor. "The quest for the right questions in the construction industry." Dispute Resolution Journal 57, no. 3 (2002): 8. 
[7] LTSF. "Litigation Trends Survey Findings, The ninth annual report of the LTSF”. Fulbright and Jaworski L.L.pp (2013).

[8] Chaphalkar, N. B., and Smita K. Patil. "Decision Support System for Dispute Resolution in Construction Contracts." KSCE Journal of Civil Engineering 16, no. 4 (April 29, 2012): 499-504. doi:10.1007/s12205-012-1303-4.

[9] Treacy, T. B. (1995). Treacy, Thomas B. "Use of alternative dispute resolution in the construction industry." Journal of Management in Engineering11, no. 1 (1995): 58-63. DOI: 10.1061/(ASCE)0742-597X(1995)11:1(58).

[10] Harmon, Kathleen M. J. "Resolution of Construction Disputes: A Review of Current Methodologies." Leadership and Management in Engineering 3, no. 4 (October 2003): 187-201. doi:10.1061/(asce)1532-6748(2003)3:4(187).

[11] Gillie, P., Goetz, P., Muller, F., \& Feinberg, K. R. 'Using mediation to resolve construction disputes. Alternative dispute resolution in the construction industry (1991): 153-210. Wiley Law, New York.

[12] Ojiako, Udechukwu, Maxwell Chipulu, Alasdair Marshall, and Terry Williams. "An examination of the 'rule of law'and 'justice'implications in Online Dispute Resolution in construction projects." International Journal of Project Management (2017). DOI: 10.1016/j.ijproman.2017.10.002

[13] Storskrubb, Eva. "Alternative Dispute Resolution in the EU: Regulatory Challenges." European Review of Private Law 24, no. 1 (2016): 7-31.

[14] Chong, Heap Yih, and M. Z. Rosli. "The behaviour of dispute resolution methods in Malaysian construction industry." In Industrial Engineering and Engineering Management, 2009. IEEM 2009. IEEE International Conference on, pp. 643-647. IEEE, 2009. DOI: 10.1109/IEEM.2009.5373253.

[15] Richter, I. E. "The project neutral: Neutralizing risk, maintaining relationships and watching the bottom line." Construction Business Review 8, no. 2 (2000): 52-54.

[16] Boulle, Laurence. "A History of Alternative Dispute Resolution." ADR Bulletin 7, no. 7 (2005): 3.

[17] Barrett, Jerome T., and Joseph Barrett. A history of alternative dispute resolution: The story of a political, social, and cultural movement. John Wiley \& Sons, 2004.

[18] Ware, S. J. "Alternative Dispute Resolution (Contributions in American History)." West Group. (2001). ISBN 0314228020.

[19] Kovach, Kimberlee K. Mediation: Principles and practice. West Publishing Company, 1994.

[20] Mix, Darrick M. "ADR in the construction industry: continuing the development of a more efficient dispute resolution mechanism." Ohio St. J. on Disp. Resol. 12 (1996): 463.

[21] Glasner, Kenneth. "Contract disputes: the role of ADR." Dispute Resolution Journal 55, no. 3 (2000): 50.

[22] CPR. European Mediation and ADR Guide. International Institute for Conflict Prevention and Resolution, Inc, 2015.

[23] Sourdin, Tania Michelle. "Legislating for Alternative Dispute Resolution: A Guide for Government Policy Makers and Legal Drafters." (2006).

[24] Margaret "Peggy" Landry and James P. Groton. The Standing Neutral-Low-Cost Insurance to Prevent Disputes on Construction Projects. (2014).

[25] Menassa, Carol Chukri. Quantitative framework to evaluate alternative dispute resolution investments in architecture engineering and construction projects using option and real option theory. University of Illinois at Urbana-Champaign, 2009.

[26] ASCE. Avoiding and resolving disputes during construction: successful practices and guideline, the technical committee on contracting practices of the underground technical research council of ASCE. ASCE Press, New York, N.Y, 1991.

[27] AAA. Construction Industry Arbitration Rules. American Arbitration Association. New York, 2000.

[28] Macneil, Ian R., Richard E. Speidel, and Thomas J. Stipanowich. Federal arbitration law: agreements, awards, and remedies under the Federal Arbitration Act. Vol. 2. Little, Brown, 1994.

[29] Rubin, R. A., R. A. Cohan, and P. M. Lurie. "Beyond Arbitration: Alternatives to Binding Dispute Resolution in the Construction Industry." Construction Contracts and Litigation in the Economically Troubled 90's, KM Cushman, ed., Practicing Law Institute, New York (1991): 959-985.

[30] Jones, D. "A Critical Analysis of the Means Commonly Adopted to Avoid Disputes in the Construction Industry." Building and Construction Law 14 (1998): 31-52.

[31] Costello Jr, E. J. ADR: virtue or vice? Dispute Resolution Journal 54, 2 (1999):62.

[32] AGC. Standard form of agreement and general conditions between owner and contractor (where the contract price is a lump sum). The Associated General Contractors of America. Washington, DC, 1997. 
[33] Cronin-Harris, C. Mainstreaming: Systematizing Corporate Use Of ADR, Symposium on Business Dispute Resolution: ADR and Beyond. Alb. L. Rev., 59 (1996) 847.

[34] Goodman, A. H. "General services administration board of contract appeals extend to ADR-An overview." The Construction Contractor 21, no. 9 (1997): 3-6.

[35] Stipanowich, Thomas J. "Charting the Course: The 1994 Construction Industry Survey on Dispute Avoidance and Resolution." Constr. Law. 16 (1996): 8.

[36] ASFE. Alternative Dispute Resolution for the Construction Industry. Associated Soil and Foundation Engineers Published by the Association of Engineering Firms Practicing in the Geosciences. Silver Springs (1988).MD: Author.

[37] Pena-Mora, F., Sosa, C. E., \& McCone, D. S. Introduction to construction dispute resolution. Prentice Hall, 2003.

[38] CII. "Dispute Prevention and Resolution Techniques in the Construction Industry." Prepared by the Dispute Prevention and Resolution Research Team, Construction Industry Institute, Research Summary 23-1, (1995). The University of Texas at Austin.

[39] Ross, D. Construction Disputes Resolution. (n.d.). From http://www.layngross.com

[40] Kennedy, Peter. "Evolution of statutory adjudication as a form of dispute resolution in the UK construction industry." Journal of Professional Issues in Engineering Education and Practice134, no. 2 (2008): 214-219. DOI: 10.1061/(ASCE)10523928(2008)134:2(214).

[41] Ndekugri, Issaka, and Victoria Russell. "Insolvency and resolution of construction contract disputes by adjudication in the UK construction industry." Construction Management and Economics 23, no. 4 (2005): 399-408. DOI: 10.1080/0144619042000326747.

[42] McGaw, M. C. "Adjudicators, experts and keeping out of court." Construction Law Journal 8 (1995): 332-332.

[43] Groton, James P. "Dispute review boards-backdoor partnering." The Dispute Avoidance and Resolution Task Force (DART). American Arbitration Association, New York, NY (1993).

[44] AAA. Glossary of Dispute Resolution Terms. American Arbitration Association. New York, 2004.

[45] Fenn, Peter, and Rod Gameson. Construction conflict management and resolution. Routledge, 2003.

[46] IAFL. "Private Judge, International Academy of Family Lawyers". (n.d) from http://www.iafl.com.

[47] Smith, Currie, and Hancock. Common Sense Construction Law: A Practical Guide for the Construction Professional, John Wiley \& Sons, Inc., Hoboken, New Jersey, 2009.

[48] Stipanowich, Thomas J. "Contract and conflict management." Wis. L. Rev. (2001): 831.

[49] Rebach, Howard M. "Mediation and alternative dispute resolution." In Handbook of clinical sociology, pp. 197-224. Springer, Boston, MA, 2001.

[50] Brunet, Edward J., and Charles B. Craver. Alternative dispute resolution: the advocate's perspective. Lexis Nexis Matthew Bender, 2001.

[51] Fisher, Ron. "Methods of third-party intervention." (2001). From: http://edoc.vifapol.de/opus/volltexte/2011/2579/

[52] Ranjbar, A. Alternative dispute resolution methods in internal law. Islamic Parliament Research Center of the Islamic Republic Of IRAN, 2003. (In Persian)

[53] Evans, John Orville. "Resolving design and construction disputes: Selecting alternative dispute resolution techniques and selecting neutrals." PhD diss., Texas A \& M University, 1993.

[54] Creswell, John W. Research design: Qualitative, quantitative, and mixed methods approaches. Sage publications, 2009.

[55] Saunders, Mark NK. Research methods for business students, 5/e. Pearson Education India, 2011.

[56] Green, Samuel B., and Neil J. Salkind. Using SPSS for Windows and Macintosh: Analyzing and understanding data. Prentice Hall Press, 2010.

[57] Habibpour and Safari. "A comprehensive guide to use SPSS for quantitative data analysis". Motafakeran Publisher, Tehran, 2015. (In Persian)

[58] Hair, Joseph F., William C. Black, Barry J. Babin, Rolph E. Anderson, and Ronald L. Tatham. Multivariate data analysis. Vol. 5, no. 3. Upper Saddle River, NJ: Prentice hall, 1998.

[59] Mansourfar, K. “Advanced statistical methods: Comes with computer programs”. University of Tehran, Tehran, 2007. (In Persian)

[60] Cattell, Raymond B. "The scree test for the number of factors." Multivariate behavioral research 1, no. 2 (1966): 245-276. DOI: 
10.1207/s15327906mbr0102_10.

[61] Sarookhani. "Research methods in the social sciences: Principles and Foundations". Enteshârâte pazoheshgâhe elomeh ensâni v motâleâte farhangi. Tehran, 2004. (In Persian) 
Appendix I: Questionnaire

\section{Neutral in Construction Dispute Resolution methods}

1. What kind of below license do you have?

Check all that apply.

a. Court official expert

b. Civil (of construction engineering organization)

c. Architecture (of construction engineering organization)

2. What kind of following experience do you have in construction industry? Check all that apply.
a. Contractor
b. Consultant
c. Private owner
d. Public owner
Other:

3. How long do you have experience for question 2 ? Mark only one oval.
a. Less than 10 years
b. Between 10 and 15
c. Between 15 and 20
d. More than 20 years

4. Do you currently active in a companies or organizations of construction industry? Mark only one oval.
a. Yes, contractor
b. Yes, Consultant
c. Yes, public owner
d. Yes, private owner
e. No

5. How important is a neutral person to reach a settlement in construction disputes? Mark only one oval.

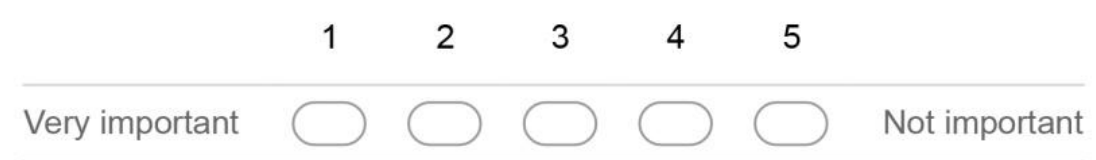


6. If you are responsible for selecting a neutral for resolving owner and contractor dispute what effect does the employment of the neutral have on your consideration:

Please choose applicable responses for each part

Mark only one oval per row.

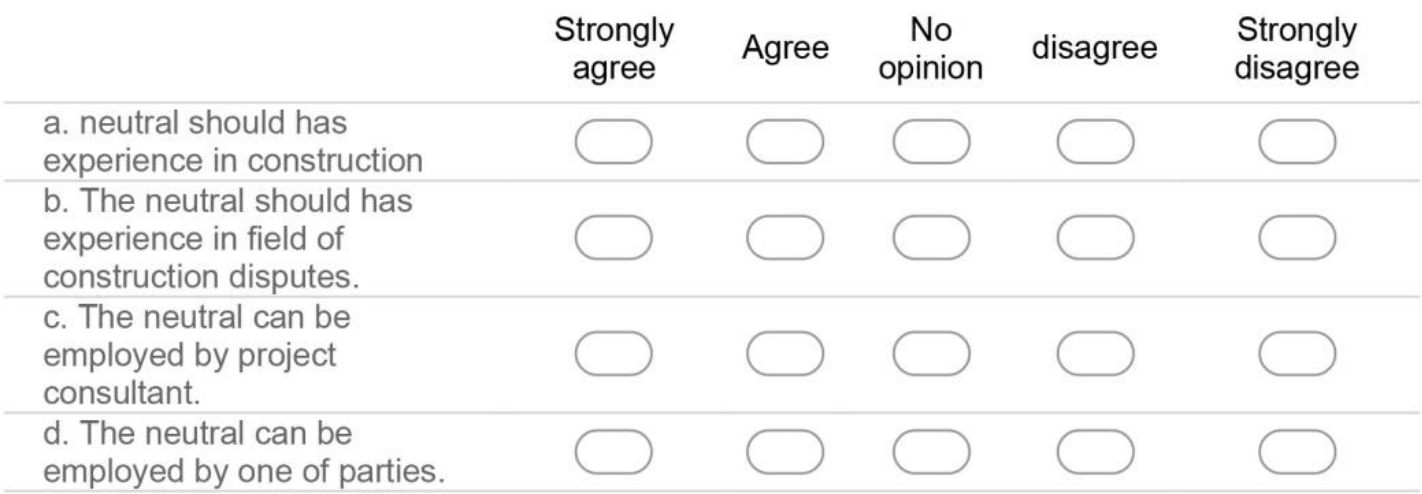

7. How important are the following experience-related technical qualifications for neutrals supporting out of court (ADR) methods for contractor and owner disputes? (For each qualification, choose your level of importance).

Please select number 1 for very important and number 5 for not important Mark only one oval per row.

a. Experience in similar project
b. Knowledge in similar
construction
c. Experience in interpreting
contract documents
d. Experience in contracting
e.Experience in similar dispute
f. Knowledge of dispute resolution
methods

8. How important do you perceive the following personal characteristics to be neutral supporting out of court (ADR) methods for contractor and owner: (for each characteristic, select your level of importance).

Please select number 1 for very important and number 5 for not important Mark only one oval per row.

a. Non-biases
b. Patient
c. Good listener
d. Good communicator
e. No emotional
f. Honest
i. Humble
k. Opendicious temperament
I. Fair
m. Don't give opinion without
evidence and document
n. No interest of conflict.


9. What kind of out-of-court dispute resolution (ADR) methods are you familiar?

10. This page is an open invitation for any additional comments. Please write your comments.

11. If you want to know the results of this research, please write your email address. 